\title{
INVESTIGATIONS OF THE INFLUENCE OF POLYSTYRENE FOAMED GRANULES ON THE PROPERTIES OF LIGHTWEIGHT CONCRETE
}

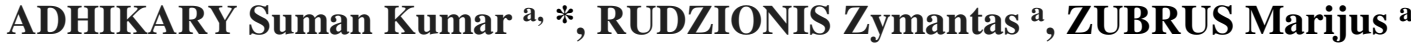 \\ ${ }^{\mathrm{a}}$ Kaunas University of Technology, Civil Engineering and Architecture, e-mail: sumankradk9s@ gmail.com
}

Received: 24.12.2018 / Accepted: 14.03.2019/ Revised: 11.04.2019 / Available online: 31.05.2019

DOI: 10.2478/jaes-2019-0002

KEY WORDS: Lightweight concrete; thermal conductivity; polystyrene foam concrete; Microscopic analysis.

\begin{abstract}
:
This paper deals with the behaviour of cement paste upon the addition of crushed polystyrene foam. Crushed polystyrene foam waste with a fill density of $13.97 \mathrm{~kg} / \mathrm{m}^{3}$ and hydrated lime were used to prepare the foam. Three different types of samples S-1, S-2, and S3 were prepared to observe the behaviour of cement pastes after the addition of different doses of foam in constant water/cement ratio. The volumetric ratio of EPS and cement paste were 1: 1.294; $1: 0.863$; and 1: 0.647 . In each type of sample, 0.28 water/cement ratio is maintained. Slump test was carried out in the fresh state and it has been found slump value was decreasing by increasing foam content in concrete sample. On the $7^{\text {th }}$ and $28^{\text {th }}$ day of curing process, the compressive strength test was carried out. Compressive strength and density of concrete samples also decreasing by addition of higher foam content. In addition, water absorption test and microscopic analysis tests were carried out on the $28^{\text {th }}$ day of curing process. It has been found from the study that samples thermal conductivity is working proportionally.
\end{abstract}

\section{INTRODUCTION}

The whole world pays great attention to the environmental protection and is trying to recycle waste materials. Every year the amount of the polystyrene waste is increasing and ultimately causing environmental pollution and harm the ecosystem. Polystyrene also known as EPS (Expanded polystyrene) is highly popular material used as packaging and insulation material. Polystyrene is large and bulky in nature and takes significant space for disposal. This material is also nonbiodegradable and cannot be disposed easily. On the other hand, this material is lightweight with good thermal and sound insulation properties [1, 2, and 3]. The density of expanded polystyrene is extremely light and the it varies $12-20 \mathrm{~kg} / \mathrm{m}^{3}$. So, this material has gained great popularity in construction industry. Waste polystyrene can be used in construction industry as various options like preparation of lightweight concrete, as aggregates and foams [4, 5, and 6]. Generally convectional concrete density is around $2400 \mathrm{~kg} / \mathrm{m}^{3}$ and lightweight concrete is subjected to having density around 1800 $\mathrm{kg} / \mathrm{m}^{3}$ or less [7]. There are several materials used to prepare lightweight concrete such aluminum powder (foaming agent), mineral lightweight aggregates (vermiculite perlite, pumice, slate, expanded shale, etc.), polymer materials and other lightweight aggregates [8,9]. Polystyrene based light weight concrete was firstly tested in 1996 by Dr. Z. Kuhai [10]. Researcher WU Zhen achieved light weight concrete with the density of less than $500 \mathrm{~kg} / \mathrm{m}^{3}$ by replacing fine aggregate by EPS foam and found in his experimental studies that compressive strength of EPS foam-based concrete is proportional to its bulk density [11]. Several studies have been conducted with polystyrene and other admixtures in concrete like fly ash, different types of fibers, silica fume, polymeric admixtures etc. [12, 13, and 14]. Polystyrene aggregates are commercially available worldwide while most of the plants are concentrated in Europe and Russia [15]. It has been found that EPS aggregate concrete has higher compressive strength with fire resistance properties than perlite aggregate concrete [16]. EPS concrete have various beneficial aspects and its strength can be improved by adding some admixtures. The main purpose of this paper is quantifying the influence of the concrete under various EPS foam doses.

\section{MATERIALS AND PROPORTIONS OF MIXING}

Ordinary Portland cement named 'Akmenès Cementas AB' of grade CEM I 42.5R satisfying EN 197-1:2011 was used. Crushed polystyrene foam granule of $13.97 \mathrm{~kg} / \mathrm{m}^{3}$ density and hydrated lime were used to prepare the foam. To prepare the foam, crushed polystyrene and water were used in a ratio of 1:4 by volume and $20 \%$ hydrated lime of its volume used. Water crashed polystyrene and hydrated lime mixed with compressor airflow to produce foam. Afterwards foam was mixed with cement paste manually by hand and proceed for slump test and moulding process which is showed in Figure 1. The composition of all samples can be seen in Table 1 .

\footnotetext{
* Corresponding author: Suman Kumar Adhikary, e-mail: sumankradk9s@gmail.com
} 
Table 1 . The mixing composition the samples for $1 \mathrm{~m}^{3}$ concrete

\begin{tabular}{|c|c|c|c|}
\hline $\begin{array}{c}\text { Type of } \\
\text { samples }\end{array}$ & $\begin{array}{c}\text { Cement } \\
\text { quantity, } \mathrm{kg}\end{array}$ & $\begin{array}{c}\text { Amount } \\
\text { of water, } \\
\mathrm{kg}\end{array}$ & $\begin{array}{c}\text { Foam } \\
\text { quantity, } \mathrm{kg}\end{array}$ \\
\hline $\mathrm{S}-1$ & 875.0 & 366.7 & 21.3 \\
\hline S-2 & 841.2 & 352.5 & 30.4 \\
\hline S-3 & 656.7 & 275.2 & 31.6 \\
\hline
\end{tabular}
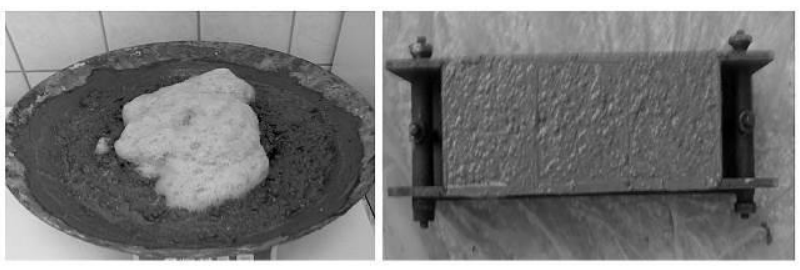

Figure 1. Mmixing foam with cement morter and Moulded concrete

\section{MECHANICAL PROPERTIES EVOLUTION}

\section{Slump}

Slump test was carried out after mixing the cement paste in fresh state by using Sutardo viscosimeter satisfying GOST (23789-85) standard. Sutardo viscosimeter is a cylindrical shaped equipment having $57 \mathrm{~mm}$ external diameter with $50 \mathrm{~mm}$ internal diameter and $99.5 \mathrm{~mm}$ of height. Slump test of each type of specimens were carried out in two stages. Firstly, slump test was carried out without foam content and in the $2^{\text {nd }}$ stage, foam was mixed with the cement paste. The slump test was carried out in two stages to determine the difference of slump value when foam is added to the concrete. From the study, it has been found that slump value of the mixture decreases with increasing foam. By increasing the volume of foam up to their volumetric concentration with a 1: 0.436 cement, the spread of the mixture decreased by $18.75 \%$. This could be explained by the fact that by increasing the amount of foam the water absorption also increases and results less slump value. The result of slump test can be seen in Figure 2 .

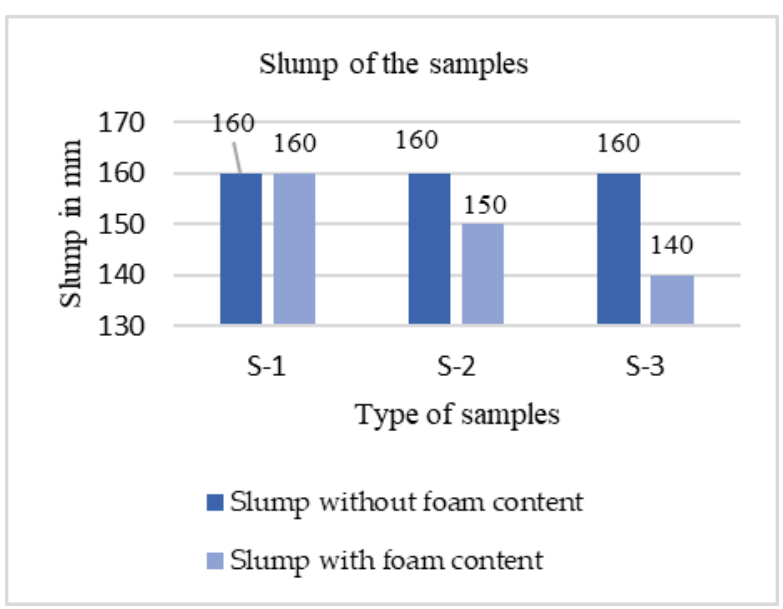

Figure 2. Slump test of concrete samples

\section{Compressive strength}

After the slump test all the samples were moulded in $7.07 \mathrm{~cm} \mathrm{x}$ $7.07 \mathrm{~cm} \times 7.07 \mathrm{~cm}$ size cubes to determine the water absorption test, density, compressive strength. Each type of samples was prepared in three same specimens and average value was taken as result. The molding samples were kept in room temperature for 24 hours for the hardening process. After hardening process, all samples were kept in curing chamber (temperature $20 \pm 2{ }^{\circ} \mathrm{C}$ and relative humidity $95 \%$ or more) till the day of test. Compressive strength test was conducted on $7^{\text {th }}$ and $28^{\text {th }}$ day of curing process satisfying LST EN 12390-3: 2001 norms. Before testing the strength properties, the samples were removed from curing chamber and kept 1 to 2 hours in room temperature. The results of the compressive test showed in Figure 3. From the results of the study it has been found that the compressive strength decreases with increasing the amount of crushed polystyrene foam granules. This can be explained by the fact that the strength of the polystyrene foam granules is less than heavy aggregates. Therefore, the strength properties of the specimens were reduced.

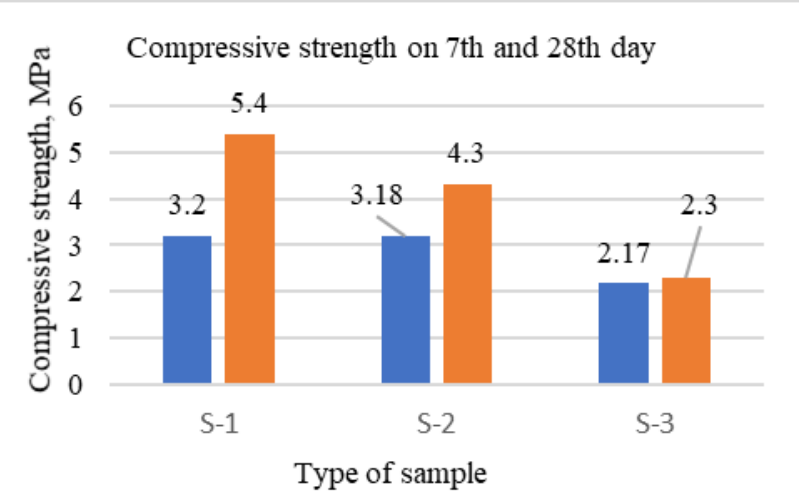

7th day compressive test $\quad 28$ th day compressive test

Figure 3. Compressive strength test of concrete samples on $7^{\text {th }}$ and $28^{\text {th }}$ day

\section{Density test}

The average density of specimens was determined in fresh and hardened state. After the curing process on $28^{\text {th }}$ day water immersed concrete samples were taken out from the climatic chamber and dried in room temperate for 6 hours. After the drying process concrete samples density were calculated. From the result it has been found that density and doses of polystyrene foam is inversely proportional. It means the density of concrete specimen's decreases with the increasing volume of polystyrene foam in the concrete mixture. Figure 4 shows the density of concrete samples on fresh and hardened state. 


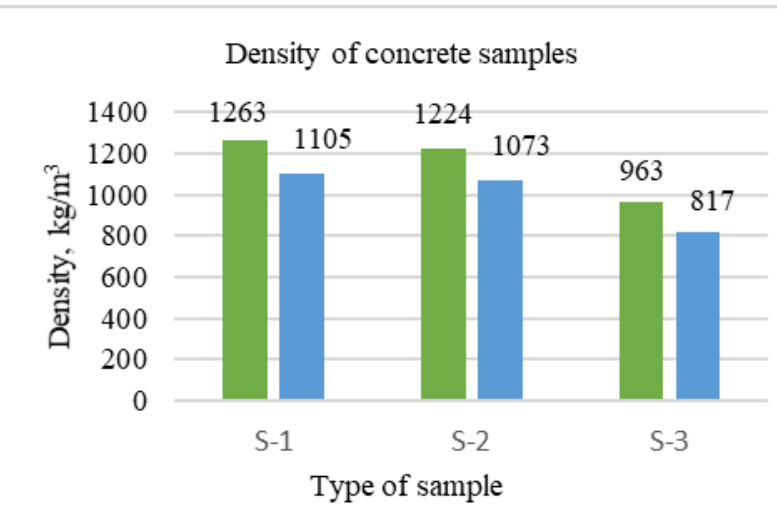

Density in fresh state $\square$ Density in hardened state

Figure 4. Density of concrete samples

\section{Water absorption test}

The water absorption of samples was determined according to the requirements of LST EN 1353: 2000. The specimens were placed in water and weighed in balance after $15 \mathrm{~min}, 1 \mathrm{~h}, 24 \mathrm{~h}$ and $48 \mathrm{~h}$, and weighed by hydrostatic balance. From the results of the study it is seen that the water absorption of the specimens increases rapidly in the first minutes of soaking (up to 15 minutes), which indicates that the pores are predominant in porosity with the aid of a foam. Figure 5 shows the water absorption of concrete samples.

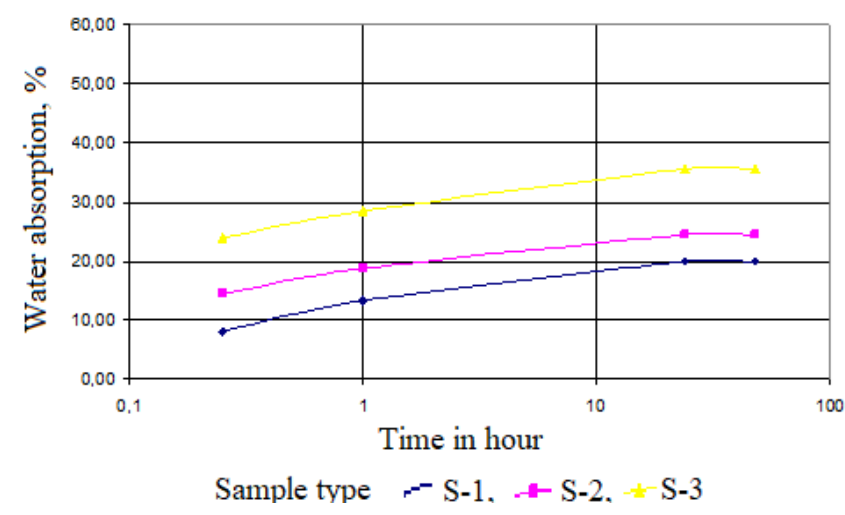

Figure 5. Water absorption test of concrete samples

\subsection{Heat transfer coefficient of specimens}

The thermal conductivity coefficient of the samples was determined according to STR 2.01.03: 2003 showed in Figure 6. After calculating the curve, which is given in Figure 7, the thermal conductivity coefficients of the samples are deduced according to the curve equation. The coefficient of determination $\mathrm{R}^{2}=0.9925$.

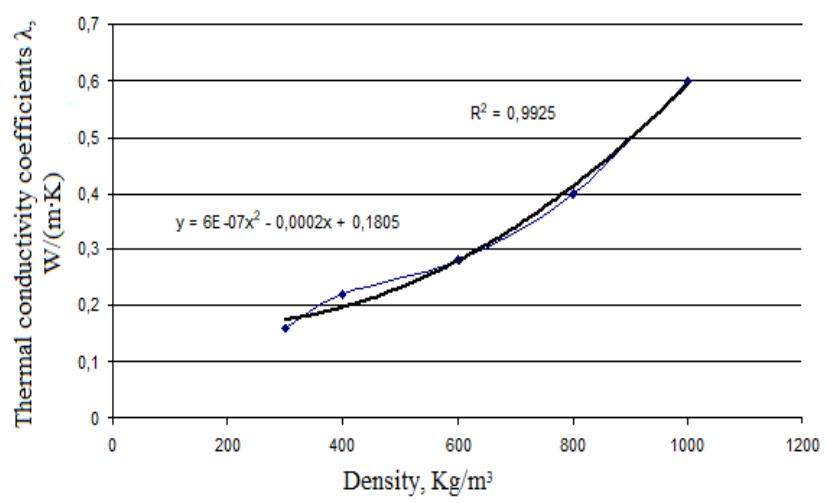

Figure 6 . Thermal conductivity coefficient chart by density of samples

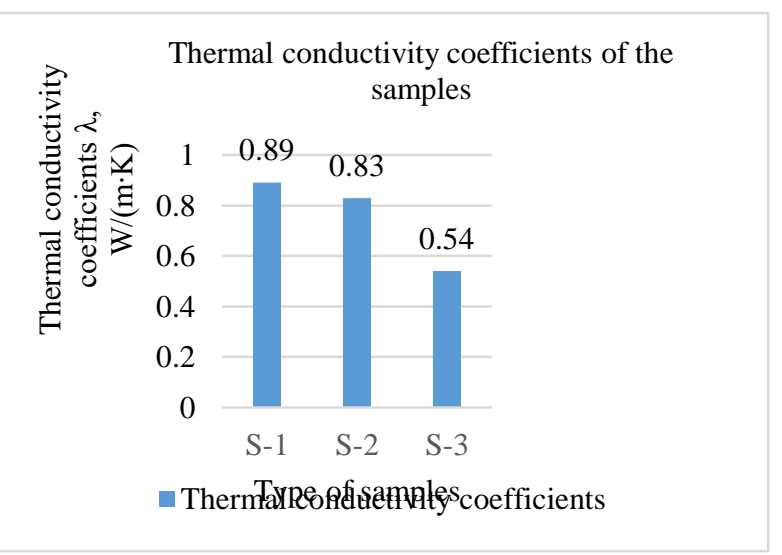

Figure 7. Calculated thermal conductivity coefficients of samples

\subsection{Microscopic analysis}

Microscopic analysis of concrete provides information about microstructure of concrete and mineral constituents. Material scanning electron microscopy (SEM) was performed using the FEI QUANTA 200F microscope. The FEI Quanta 200 FEG's high-resolution scanning electron microscope provides an Outdoor Schottky Area Cannon (FEG). The following operating conditions were used for scanning: high vacuum (HV) mode - 5 $\mathrm{kV}$. The microscopic analysis was carried out on samples $\mathrm{S}-1$, $\mathrm{S}-2$, and S-3. The analysis was carried out on samples bulk of the texture. Microscopic analysis and EDX (Energy-Dispersive $\mathrm{X}$-Ray) analysis of sample S-1, S-2, and S-3 are shown in Figure 8 and Figure 9, Figure 10, Figure 11, Figure 12 and Figure 13. 


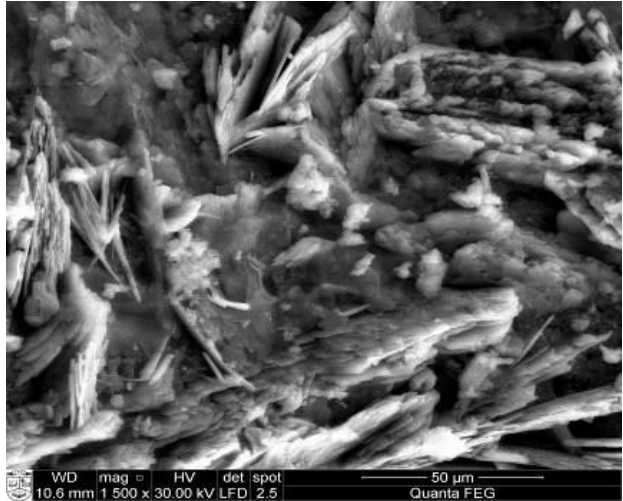

Figure 8. Sample S-1 micscopic analysis on the bulk texture

Spectrum: $1113 \mathrm{ca}$

\begin{tabular}{|c|c|c|c|c|c|}
\hline Element & Series & $\begin{array}{l}\text { unn. C } \\
{[w t . \%]}\end{array}$ & $\begin{array}{r}\text { norm. C } \\
\text { [wt. \% ] }\end{array}$ & $\begin{array}{r}\text { Atom. C } \\
{[\text { at. } \%]}\end{array}$ & $\begin{array}{r}\text { Error } \\
{\left[\frac{\circ}{8}\right]}\end{array}$ \\
\hline Carbon & K-series & 0.90 & 0.73 & 1.26 & 0.3 \\
\hline Oxygen & K-series & 73.40 & 58.91 & 76.49 & 40.8 \\
\hline Sodium & K-series & 0.08 & 0.07 & 0.06 & 0.0 \\
\hline Magnesium & K-series & 0.90 & 0.72 & 0.62 & 0.1 \\
\hline Aluminium & K-series & 1.30 & 1.04 & 0.80 & 0.1 \\
\hline Silicon & K-series & 5.45 & 4.38 & 3.24 & 0.3 \\
\hline Sulfur & K-series & 0.87 & 0.70 & 0.45 & 0.1 \\
\hline Potassium & K-series & 0.54 & 0.43 & 0.23 & 0.0 \\
\hline Calcium & K-series & 38.78 & 31.12 & 16.13 & 1.2 \\
\hline Titanium & K-series & 0.32 & 0.26 & 0.11 & 0.0 \\
\hline Iron & K-series & 2.04 & 1.64 & 0.61 & 0.1 \\
\hline
\end{tabular}

Figure 9. Sample S-1 Energy-Dispersive X-Ray analysis

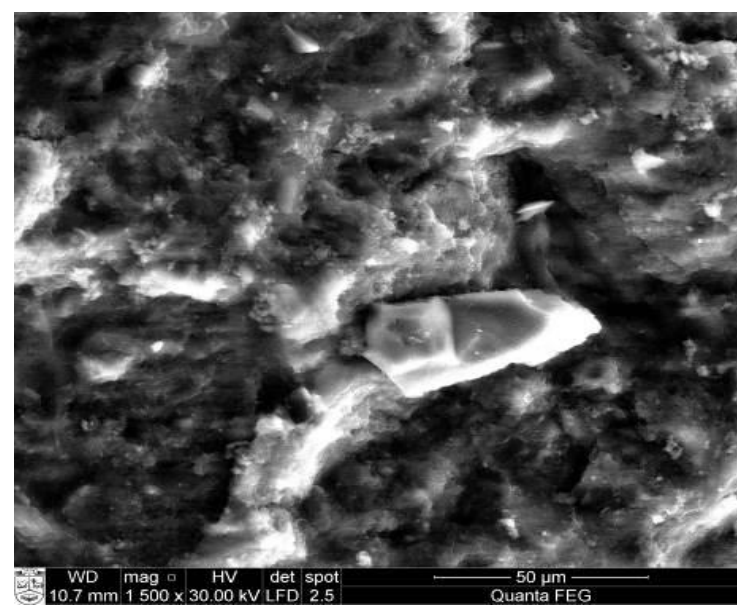

Figure 10. Sample S-2 micscopic analysis on the bulk texture
Spectrum: 0-normal $12 \mathrm{CaCO} 3$

\begin{tabular}{|c|c|c|c|c|c|}
\hline lement & Series & $\begin{array}{l}\text { unn. C } \\
\left.\text { [wt. } \frac{\circ}{8}\right]\end{array}$ & $\begin{array}{r}\text { norm. C } \\
{[\text { wt. } \%]}\end{array}$ & $\begin{array}{l}\text { Atom. C } \\
\text { [at. } \%]\end{array}$ & $\begin{array}{r}\text { Error } \\
{\left[\frac{\%}{8}\right]}\end{array}$ \\
\hline Carbon & K-series & 10.18 & 10.45 & 18.23 & 6 \\
\hline Oxyg & K-series & 40.68 & 41.78 & 54.68 & 29. \\
\hline Sodium & K-series & 0.17 & 0.18 & 0.16 & 0.0 \\
\hline Magnesium & K-series & 0.74 & 0.76 & 0.66 & ). \\
\hline Aluminium & K-series & 1.00 & 1.03 & 0.80 & 0. \\
\hline Silicon & K-series & 7.27 & 7.47 & 5.57 & 0. \\
\hline Sulf & $\mathrm{K}-\mathrm{se}$ & 0.64 & 0.66 & 0.43 & 0 \\
\hline Potassium & K-series & 1.13 & 1.16 & 0.62 & 0. \\
\hline Calcium & K-series & 33.96 & 34.88 & 18.23 & 1.0 \\
\hline Titanium & K-series & & & 0.12 & 0.0 \\
\hline Iron & K-series & 1.31 & 1.35 & 0.51 & 0. \\
\hline
\end{tabular}

Figure 11. Sample S-2 Energy-Dispersive X-Ray analysis

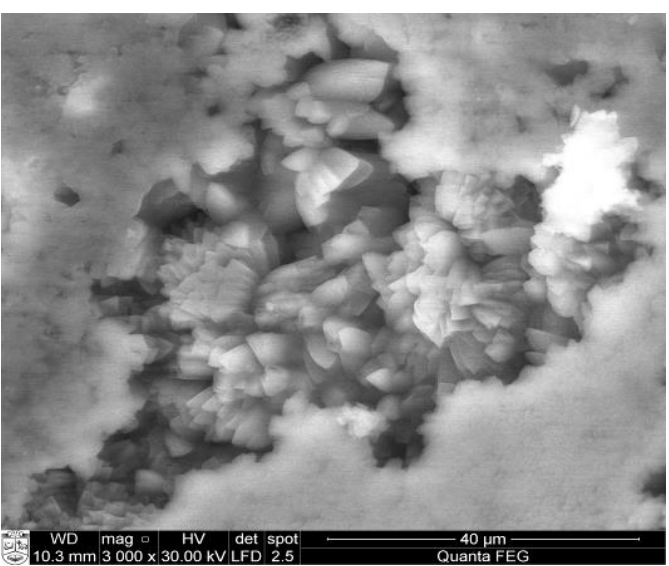

Figure 12. Sample S-3 micscopic analysis on the bulk texture

Spectrum: 3115 pavirsius

\begin{tabular}{|c|c|c|c|c|c|}
\hline Element & Series & $\begin{array}{l}\text { unn. C } \\
{[w t . \%]}\end{array}$ & $\begin{array}{r}\text { norm. C } \\
{[w t . \%]}\end{array}$ & $\begin{array}{l}\text { Atom. C } \\
{[\text { at. \% ] }}\end{array}$ & $\begin{array}{r}\text { Error } \\
{\left[\frac{\%}{\%}\right]}\end{array}$ \\
\hline Carbon & K-series & 0.01 & 0.01 & 0.03 & 0.1 \\
\hline Oxygen & K-series & 21.83 & 21.83 & 40.62 & 9.2 \\
\hline Magnesium & K-series & 0.10 & 0.10 & 0.12 & 0.0 \\
\hline Aluminium & K-series & 1.88 & 1.88 & 2.08 & 0.1 \\
\hline Silicon & K-series & 2.00 & 2.00 & 2.12 & 0.1 \\
\hline Sulfur & K-series & 0.45 & 0.45 & 0.42 & 0.0 \\
\hline Potassium & K-series & 0.29 & 0.29 & 0.22 & 0.0 \\
\hline Calcium & K-series & 72.66 & 72.66 & 53.98 & 2.2 \\
\hline Iron & K-series & 0.79 & 0.79 & 0.42 & 0.0 \\
\hline
\end{tabular}

Figure 13. Sample S-3 Energy-Dispersive X-Ray analysis

\section{$1.7 \mathrm{X}$-ray diffraction analysis}

$\mathrm{X}$-ray diffraction is a very useful technique to identify the crystalline phases of cement in concrete [17]. X-ray diffraction analysis was performed using the DRON-6 diffractometer. $\mathrm{CuKa}$ radiation, $\mathrm{Ni}$ filter was used for the test, detector movement step was $0.02^{\circ}$, intensity measurement $0.5 \mathrm{~s}$, anode voltage $\mathrm{U}_{\mathrm{a}}=30 \mathrm{kV}$, current $\mathrm{I}=20 \mathrm{~mA}$. The diffraction curves 
were additionally recorded in the range of $2 \div 60^{\circ} 2 \theta$ angles using a flat-end graphite monochromator $(\mathrm{d}=0.355 \mathrm{~nm})$ and measuring the intensity $\tau=1 \mathrm{~s}$. X-ray diffraction analysis was performed on samples S-1, S-2 and S-3. The results of the study are presented in Figure.14 X-ray images of the specimens have identified the diffraction peaks that are characteristic of Portlandites(P), Calcium carbonate(C), Alitas(A), Vateritas(V), Etringitas(E). From the Figure 14 it can be clearly observed that the Portlandite is at peak level at $18^{\circ}$ for sample S- 1 while samples S-2 and S-3 have lesser peak level. On the other hand, Alitas was at peak level at $29.1^{\circ}$ for sample S-3 while samples S1 and S-2 show lesser peak level.

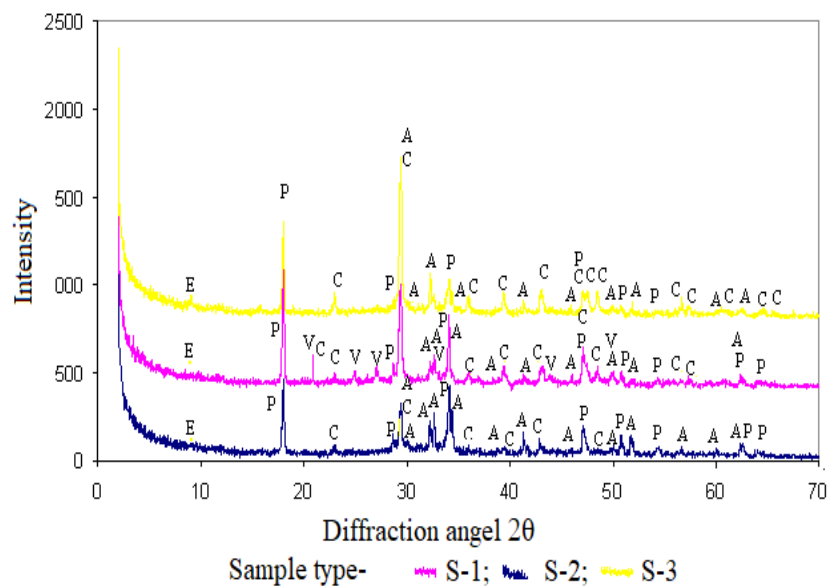

Figure 14. X-ray diffraction analysis curves of samples

\section{CONCLUSION}

From the study it has been found that the workability of polystyrene foamed concrete depends upon the ratio of polystyrene foam and cement paste. Density, compressive strength of the concrete is inversely proportional to the doses of polystyrene foam in the concrete. Concrete's density and strength decreases when the amount of polystyrene foam increases in the concrete mixture. Samples S-1, and S-2 have better compressive strength compared to $\mathrm{S}-3$. On the other hand, S-3 has better thermal insulation conductivity. Sample S3 can be used in construction sector because it has enough strength properties and thermal conductivity coefficient. The insulation and strength properties of polystyrene foamed concrete can be improved by using micro fillers and thermal insulating admixtures like aerogel. In future, further study will be carried out to achieve higher strength and thermal conductivity in lightweight concrete. And new materials like aerogel, carbon aerogel will be developed and used in light weight and ultra-light weight concrete to achieve better thermal coefficient.

\section{References}

Xu, Yi \& Jiang, Linhua \& Xu, Jinxia \& Li, Yang. (2012). Mechanical properties of expanded polystyrene lightweight aggregate concrete and brick. Construction and Building Materials. 27. 32-38.
Ferrándiz-Mas, V.; García-Alcocel, E. Durability of expanded polystyrene mortars. Constr. Build. Mater. 2013, 46, 175-182.

Chen, B.; Liu, J.; Chen, L.Z. Experimental Study of Lightweight Expanded Polystyrene Aggregate Concrete Containing Silica Fume and Polypropylene Fibers. J. Shanghai Jiaotong Univ. Sci. 2010, 15, 129-137.

Dr. G. Elangovan , "Experimental study on light weight concrete by partial replacement of fine aggregate using flyash and adding thermocol", International Journal on Engineering Technology and Sciences, Volume II, Issue IX, September2015.

KAYA, Ayse \& Kar, Filiz. (2016). Properties of concrete containing waste expanded polystyrene and natural resin. Construction and Building Materials. 105. 572-578. 10.1016/j.conbuildmat.2015.12.177.

Marcelo Amianti; Vagner Roberto Botaro, Recycling of EPS: A new methodology for production of concrete impregnated with polystyrene (CIP), Cement and Concrete Composites, Vol: 30, Issue: 1, Page: 23-28, 2008.

S.G. Park and D.H. Chisholm, Polystyrene Aggregate Concrete, Building Research Association of New Zealand, Study report SR 85, Judgeford, New Zealand, 1999.

R. Madandoust, M. Muhammad Ranjbar, S. Yasin Mousavi, Constr Build Mater 25 (2011) 3721-3731.

Yi Xu, L. Jiang, J. Xu, Y. Li, Constr Build Mater 27 (2012) 32-38.

Z. Kuhai, Polystyrene-lightweight Concrete, Annajah University Journal, Nablus, Palestine, under publication.

WU Zhen, CHEN Bing, LIU Ning "Fabrication and Compressive Properties of Expanded Polystyrene Foamed Concrete: Experimental Research and Modeling", Journal of Shanghai Jiaotong University (Science)18(1), 2013.

B. Chen and J. Liu, "Properties of lightweight expanded polystyrene concrete reinforced with steel fiber," Cement and Concrete Research, vol. 34, no. 7, pp. 1259-1263, 2004.

D. S. Babu, G. K. Babu, and W. Tiong-Huan, "Properties of lightweight expanded polystyrene aggregate concretes containing fly ash," Cement and Concrete Research, vol. 35, no. 6, pp. 1218-1223, 2005.

W. C. Tang, Y. Lo, and A. Nadeem, "Mechanical and drying shrinkage properties of structural-graded polystyrene aggregate concrete," Cement and Concrete Composites, vol. 30, no. 5, pp. 403-409, 2008.

B. Chen and J. Liu, "Mechanical properties of polymermodified concretes containing expanded polystyrene beads," Construction and Building Materials, vol. 21, no. 1, pp. 7-11, 2007.

A. Short, W. Kinniburgh, Lightweight concret, ISBN10 0853347344 . 
P. Klug, Leroy E. Alexander, X-Ray Diffraction Procedures: For Polycrystalline and Amorphous Materials, 2nd Edition Harold. 